\title{
THE NATURE OF SERVICES PROVIDED BY COLLABORATIVE PLATFORMS*
}

\author{
JUDr. Laura Rózenfeldová, PhD Candidate \\ P. J. Šafárik University in Košice, Faculty of Law \\ Kováčska 26, 04001 Košice, Slovakia \\ laura.rozenfeldova@student.upjs.sk
}

\begin{abstract}
The objective of this paper is to analyse the nature of services provided by collaborative platforms. In this regard, we consider the approach established by the European Commission in its European Agenda on Collaborative Economy, as well as the individual decisions of the Court of Justice which examined the nature of services provided by collaborative platforms Uber and Airbnb. On this basis we formulate the criteria that enable the classification of services provided by collaborative platforms as information society services or as underlying services. As the following step in this analysis we argue that it is necessary to establish not only the nature of services provided by collaborative platforms, but also the nature of the contractual relationships concluded between subjects participating in the collaborative economy.
\end{abstract}

Keywords: collaborative economy, collaborative platforms, service, underlying service, information society service, ancillary service

\section{INTRODUCTION}

The nature of commercial transactions performed in the digital environment differs from the traditional commercial transactions realised offline. ${ }^{1}$ This is also the case of commercial transactions performed in the collaborative economy defined by the Commission as referring to "business models where activities are facilitated by collaborative platforms that create an open marketplace for the temporary usage of

This paper is funded by the Slovak APVV project under contract No. APVV-14-0598 and by the APVV project under contract No. APVV-17-0561.

1 See Hučková, R.; Červená, K., Commerce and Technological Development, DAYS OF LAW, 2014, part 4: Technological Development and Law, Brno: Masaryk University, 2015, p. 99-107 
goods or services often provided by private individuals." 2 This definition of the collaborative economy illustrates the fact that commercial activities realised in the digital single market ${ }^{3}$ are enabled by the existence and functioning of the new market participants - collaborative platforms - that facilitate temporary usage of goods and services on the market provided primarily by individuals as private persons outside the scope of their primary activities (employment, business).

It is necessary to point out that the commercial activities realised in the collaborative economy do not present new or innovative activities. In contrast, these transactions consist of the sale of goods or the provision of services that can also be realised by matching the supply and demand in a traditional setting. However, the specific feature of the commercial transactions performed in the collaborative economy is the widening of the previous bilateral relationships to multilateral relationships, where a new subject - collaborative platform - intermediates transactions between the concerned parties. Therefore, we can distinguish three main participants in the collaborative economy:

a) "service providers who share assets, resources, time and/or skills - these can be private individuals offering services on an occasional basis ('peers') or service providers acting in their professional capacity ('professional service providers');

b) users of these; and

c) intermediaries that connect - via an online platform - providers with users and that facilitate transactions between them ('collaborative platforms')."4

The participation of the collaborative platform on the commercial transaction consists of the creation of an online environment that simplifies the matching of supply and demand between the service providers and their users. The commercial transaction is later performed offline - outside the collaborative platform.

Another specific feature of the commercial transactions in the collaborative economy is the fact that these transactions usually do not involve a change of ownership, as the service providers only offer assets which they already own and which

2 Communication from the Commission to the European parliament, the Council, the European Economic and Social Committee and the Committee of Regions. A European Agenda for the Collaborative Economy. (SWD (2016) 184 final). p. 3

3 For a definition of the digital single market and its features within the European Union see e. $g$. Trešćáková, D. The Impact of Digitalization and Innovation in International Trade, Cifrovoje parvo, Moscow: Prospekt, 2020, p. 250

4 Communication from the Commission to the European parliament, the Council, the European Economic and Social Committee and the Committee of Regions. A European Agenda for the Collaborative Economy. (SWD (2016) 184 final). p. 3 
are utilized for other than the previously intended purpose - sharing with third persons. This can be carried out for profit or not for profit, e. g. to compensate the expenses incurred.

The issue in this regard is the question of how to assess the nature of services provided by collaborative platforms themselves. Can such services be considered as information society services provided by intermediaries where the platforms benefit from the liability exemptions as stipulated in the Directive 2000/31/EC on electronic commerce, or as underlying services provided offline? In the following chapters we will provide the analysis of the Commission's approach as well as the interpretation adopted by the Court of Justice in its decisions on the nature of services provided by collaborative platforms Uber and Airbnb. The classification of services provided by collaborative platforms either as information society services or underlying services is crucial, as it redefines the position of the collaborative platforms' operators, their rights and obligations as well as the liability that may arise if the activities of the platform do not correspond to the applicable legislation (e. g. data protection ${ }^{5}$, consumer protection ${ }^{6}$ etc.). As this question may require the adoption of a new legislation on the European Union level, the criteria established by the Commission and even more so by the Court of Justice may prove helpful in the ongoing discussion on how to regulate services provided by collaborative platforms.

\section{THE APPROACH OF THE EUROPEAN COMMISSION}

It is clear that due to the varying nature of services offered within the collaborative economy it is not easy to classify the services provided by individual collaborative platforms, as these usually do not fit neatly into one specific category. We believe that a case by case analysis will therefore be necessary, firstly to identify the services in question, secondly to analyze their nature and thirdly to classify them as information society services, underlying services or ancillary services - a classification provided by the Commission in its European Agenda on Collaborative Economy. However, the task of determining the nature of services provided by collaborative platforms is made more difficult by the fact that we must not only consider what the collaborative platform in question claims, but also whether these claims correspond to the reality. The problem in this regard arises when platforms use the

In this regard see e. g. Treščáková, D.; Hučková, R., Specific Aspects of Personal Data Protection in Electronic Commerce, Days of Law 2015: System Questions of Private Law, Brno: Masaryk University, 2016, p. 105-119

6 See e. g. Hučková, R., New Mechanisms for the Protection of Consumer Rights, Studia Iuridica Cassoviensia, 2016, p. 46-55 
classification of their services as information society services in order to make the liability exemptions as stipulated in the e-Commerce Directive applicable.

The Commission considers as the determinant relevant for the examination of the question of whether a collaborative platform provides underlying services the level of control or influence that the collaborative platform exerts over the provider of such services. This determinant allows us to consider, whether a platform does not hide under the cover of the information society service category while also acquiring benefits from exerting a significant level of control or influence over the service provider. Significant in this regard is, firstly, that the Commission does not consider the control exerted by the platform over the user and its consequences, and secondly, the scope of control or influence to be exerted in this regard in order for a minimum threshold to be met.

In order to identify the level of control or influence exerted by the platform over the provider of the service, the Commission proposed a number of factual and legislative criteria to be considered, specifically:

a) the criterion of price; It is an established practice that collaborative platforms provide tools for individual services providers used to determine the final price to be paid by the user. However, if service providers cannot differ from the price set by the platform, this may indicate that the platform controls this important aspect of the transaction (one of the key contractual terms).

b) the criterion of stipulating other key contractual terms; The question is, who sets the relevant terms and conditions, which determine the contractual relationship between the service provider and the user.

c) the criterion of ownership of key assets; In this context it is necessary to determine, who is the owner of the key assets that are shared in the individual commercial transactions (vehicle, property, professional knowledge and experience etc.).

As the Commission states, in the case of a cumulative fulfillment of all of the above mentioned criteria, there are "strong indications that the collaborative platform exercises significant influence or control over the provider of the underlying service, which may in turn indicate that it should be considered as also providing the underlying service (in addition to an information society service)."

Communication from the Commission to the European parliament, the Council, the European Economic and Social Committee and the Committee of Regions. A European Agenda for the Collaborative Economy. (SWD (2016) 184 final). p. 3 
The Commission's test to assess the nature of services provided by collaborative platforms that requires cumulative fulfillment of all of the above mentioned criteria to constitute that a collaborative platform is the provider of the underlying service, can be regarded as very strict, especially as regards the last criterion - the criterion of key assets ownership. As Devolder states, "this requirement runs counter to the very concept of the sharing economy (i. e. optimizing the use of underutilized resources by sharing them between peers)." ${ }^{\prime}$ We can assume that collaborative platforms will only rarely be considered as the owners of the assets shared, as this is in conflict with the way in which they conduct their business, the main objective of which is to connect persons in possession of the key assets with persons looking for such assets for a remuneration. Our conclusion is also supported by the analysis of the advocate general Szpunar, who stipulated when analyzing the business activities of the collaborative platform Uber, the fact that this company does not own the vehicles in question is irrelevant, since " $a$ trader can very well provide transport services using vehicles belonging to third persons, especially if he has recourse to such third persons for the purpose of those services, notwithstanding the nature of the legal relationship binding the two parties." ${ }^{.}$The fact that collaborative platforms are not the owners of key assets enables them to optimize their business activities in comparison to the functioning of traditional service providers.

We believe that the above stipulated criteria are not the only criteria to be examined when trying to determine the nature of services provided by collaborative platforms. Here, it is also necessary to consider the specific position of service providers, specifically whether they act as professional or non-professional service providers. This may also provide a tool in determining the legal relationship established between the individual service providers and the platform, which may take form of an employment relationship, commercial relationship between two professional traders or even consumer relationship (only in specific cases). On the basis of this determination it will also be possible to determine the party liable for the non-performance or defective performance of the service intermediated by the collaborative platform.

Moreover, the fact that a collaborative platform provides services other than information society services will not automatically lead to the conclusion that the collaborative platform is the provider of the underlying service, as it does not provide proof of influence and control as regards the provision of underlying service.

8 Devolder, B., Contractual Liability of the Platform, The Platform Economy. Unravelling the Legal Status of Online Intermediaries, Cambridge: Intersentia Ltd, 2019, p. 63

9 Opinion of the Advocate General Szpunar delivered on 11. May 2017, C-434/15 Asociación Profesional Elite Taxi. ECLI:EU:C:2017:364, p. 55 
The main conclusion of the Commission in this regard is a general rule, according to which "the more collaborative platforms manage and organize the selection of the providers of the underlying services and the manner in which those underlying services are carried out - for example, by directly verifying and managing the quality of such services - the more apparent it becomes that the collaborative platform may have to be considered as also providing the underlying service itself." 10

It is necessary to point out the fact that the above stipulated rules formulated by the Commission in order to define the nature of services provided by collaborative platforms are not included in a generally binding regulation or a directive, but form a part of a legally non-binding guidance. Therefore, although these guidelines should be considered, it is also possible to deviate from them, e. g. when it is necessary to take into account the specific features of the collaborative platform's activities.

\section{THE APPROACH OF THE COURT OF JUSTICE}

In contrast to the Commission, the Court of Justice (hereinafter only as "Court") approached the issue of analysing the nature of services provided by collaborative platforms and the definition of criteria relevant for such determination in a less restrictive manner. Specifically, the Court examined in its decisions the nature of services provided by collaborative platforms Uber and Airbnb, which will be closely examined below.

\subsection{Uber}

The first decision in which the Court interpreted the nature of services provided by collaborative platforms was the Judgement of the Court in the case C-454/15 Asociación Profesional Elite Taxi ${ }^{11}$ (hereinafter only as "Uber Spain"), in which the Court analysed the nature of services provided by the collaborative platform Uber.

The company Uber Technologies Inc. was established in San Francisco (USA) in 2009 and operates in Europe through a private limited liability company Uber B. V. established and localized in Holland, which is a subsidiary of the Uber Technologies Inc. (hereinafter together only as "Uber").

\footnotetext{
10 Communication from the Commission to the European parliament, the Council, the European Economic and Social Committee and the Committee of Regions. A European Agenda for the Collaborative Economy. (SWD (2016) 184 final). p. 7

11 Judgement of the Court of 20 December 2017, C-454/15 Asociación Profesional Elite Taxi. ECLI:EU:C:2017:981
} 
The Uber's Terms of Use define the services provided by Uber as services which consist of the provision of a technological platform connecting its users and unprofessional drivers, who as independent third parties provide transport and other logistical services to users. The connection between users and unprofessional drivers is realised through an application, to the use of which Uber grants users "a limited, non-exclusive, non-sublicensable, revocable, non-transferable license," 12 on the basis of contractual law. The use of this application is conditioned on the basis of a registration, after which the user can reserve a ride through the application, which will be provided by a non-professional driver within the limited territory. The payment for the provision of the transport service is realised through the application from the user's account.

Uber approaches the issue of determining the nature of services provided by the platform by defining these services as exclusively information society services. This is demonstrated in numerous provisions of its Terms of Use, where Uber requires from the user the acknowledgement of the fact that his or her "ability to obtain transportation, logistics and/or delivery services through the use of the services does not establish Uber as a provider of transportation, logistics or delivery services or as a transportation carrier." 13

The dispute in the main proceedings was the action brought by a professional taxi drivers' association Asociación Profesional Elite Taxi (hereinafter only as "Elite Taxi”) in Barcelona (Spain), which accused Uber of infringing the legislation in force as well as of misleading practices and acts of unfair competition (provision of transport services without the required licenses and authorisations). The Commercial Court No. 3 Barcelona asked the Court to interpret the relevant EU legislation to define the nature of services provided by collaborative platforms.

The Court firstly distinguished an intermediation service from a transport service by stating that "an intermediation service consisting of connecting a non-professional driver using his or her own vehicle with a person who wishes to make an urban journey is, in principle, a separate service from a transport service consisting of the physical act of moving persons or goods from one place to another by means of a vehicle." 14 According to the Court, this intermediation service meets, in principle, the criteria for classification as an 'information society service'. Here we can see that collaborative platforms usually do provide information society services. The question

12 Uber's Terms of Service, p. 3. Available online: [https://www.uber.com/legal/en/document/?name=general-terms-of-use\&country=united-states\&lang=en], accessed 20. June 2020

13 Ibid.

14 Judgement of the Court of 20 December 2017, C-454/15 Asociación Profesional Elite Taxi. ECLI:EU:C:2017:981, p. 34 
is, however, whether these are supplemented by other services or other activities of the platform that can cause the inapplicability of the relevant provisions of the e-Commerce Directive on liability exemptions.

However, the Court also stated that a service in question is more than an intermediation service as in this case the provider of that intermediation service " $s i$ multaneously offers urban transport services, which it renders accessible, in particular through software tools such as the application at issue in the main proceedings and whose general operation it organises for the benefit of persons who wish to accept that offer in order to make an urban journey." 15 The relevant aspect identified in this regard as the aspect that eliminates the possibility to define services provided by Uber as exclusively information society services is the creation of the urban transport services' offers and organisation of its operation for the benefit of the persons willing to accept such offers. The creation of the urban transport services' offers is also manifested in the fact that without the application provided by Uber "the drivers would not be led to provide transport services and persons who wish to make an urban journey would not use the services provided by those drivers." 16

Another factor identified by the Court as relevant for the analysis of the nature of services provided by Uber is the company's influence on the requirements that must be fulfilled by the non-professional drivers in order to be able to provide services using Uber's application. The Court considered in this regard the fact that Uber exercises decisive influence over these conditions, as it:

a) determines at least the maximum fare,

b) receives that amount from the client before paying part of it to the driver,

c) exercises a certain control over the quality of the vehicles,

d) exercises a certain control over the drivers and their conduct, which can, in some circumstances, result in their exclusion from the platform.

Due to the above stated determinations, the Court reached the conclusion that "intermediation service must thus be regarded as forming an integral part of an overall service whose main component is a transport service and, accordingly, must be classified not as 'an information society service' (...), but as 'a service in the field of transport." 17 In this regard the Court also pointed out that this interpretation is confirmed by the previous case law, according to which "the concept of 'services in the field of transport' includes not only transport services in themselves, but also any service inher-

\footnotetext{
$15 \quad$ Ibid. p. 38

$16 \quad$ Ibid., p. 39

17 Ibid., p. 40
} 
ently linked to any physical act of moving persons or goods from one place to another by means of transport." 18

An identical conclusion was reached by the Advocate General Szpunar, who in his Opinion similarly focused on the two aspects according to which Uber is to be considered as the provider of transport services. These include, firstly, the fact that Uber not only matches the supply to demand, but also creates the supply itself as "it also lays down rules concerning the essential characteristics of the supply and organises how it works," 19 and secondly the fact that Uber exerts control over all of the relevant aspects of a transport service (price, the minimum safety conditions as regards vehicles and drivers, recommendations as regards the time when drivers provide their services, control over the drivers' behaviour by means of the ratings systems, possibility to exclude the driver from the platform etc.).

The consequence of the classification of services provided by Uber as services in the field of transport is the exclusion of the possibility to apply the provisions of the Directive 2000/31/EC on electronic commerce on these services. In this case Uber cannot apply the liability exceptions as stipulated in Articles 12-15 of this Directive (mere conduit, caching and hosting exemptions supplemented by the prohibition of imposing a general monitoring obligation).

Moreover, the provisions of the Directive 2006/123/EC on services in the internal market $^{20}$ are also not applicable, as the Article 4 (1) (d) of this Directive expressly excludes services in the field of transport from its scope of application.

In this regard, the Article 58 (1) of the Treaty on the Functioning of the European Union (hereinafter only as "TFEU") could be applicable, as this Article in connection with the freedom to provide services in the field of transport refers to the provisions of the TFEU relating to transport. Article 90 TFEU in this regard stipulates that "the objective of the Treaties shall, in matters governed by this Title, be pursued within the framework of a common transport policy." ${ }^{21}$ However, as non-public urban transport services are not yet regulated within the scope of the European Union law, the national law of individual Member States must be considered in this regard. Therefore we can conclude that with the exception of the identification of the nature of services provided by the collaborative platform

18 See Judgement of the Court of 15 October 2015, C-168/14, Grupo Itevelesa and others. ECLI:EU:C:2015:685. p. 45-46

19 Opinion of the Advocate General Szpunar delivered on 11. May 2017, C-434/15 Asociación Profesional Elite Taxi. ECLI:EU:C:2017:364. p. 43

20 Directive 2006/123/EC of the European Parliament and of the Council of 12 December 2006 on services in the internal market. OJ L 376, 27.12.2006, p. 36-68

21 Article 90 of the Treaty on the Functioning of the European Union. OJ C 326, 26.10.2012, p. 47-390 
Uber, it is not possible to apply the relevant legislation of the European Union as regards the regulation on the conditions for the provision of intermediation services. The individual Member States will be required to deal with this issue in their own capacity.

The above stipulated conclusions were further applied by the Court in its judgement in the case C-320/16 Uber France. The Court similarly interpreted the nature of services provided by a collaborative platform - Uber France (subsidiary of the Uber B. V. company). Uber France as a defendant faced an action brought by a private person in relation to misleading commercial practices, the aiding and abetting of the unlawful exercise of the profession of taxi driver, and the unlawful organisation of a system for putting customers in contact with persons carrying passengers by road for remuneration.

The Court applied its conclusions reached in the judgement in the case C-434/15 Uber Spain. The Court specifically considered the fulfilment of the criterion of the creation of the transport services' offers and the criterion of the decisive influence exercised over the conditions for the provision of services by non-professional drivers. In this regard the Court stated that the service in question does not inherently differ from the service that was considered in the case C-434/15 Uber Spain. Due to this the Court stated that the examined national law "concerns a 'service in the field of transport' in so far as it applies to an intermediation service that is provided by means of a smartphone application and forms an integral part of an overall service the principal element of which is the transport service." 22

In conclusion we can state that both of the above analysed decisions of the Court considered the question of whether the intermediation service, which consists of connecting individual persons with non-professional drivers by means of an online platform (online component), and the transport service (offline component) form two separate services that must be distinguished and that require the application of different legal regimes, or whether these services form one service of a mixed nature, where the transport service is the primary part of the service, while the intermediary service is only of supplementary nature. These decisions conclude that due to the fact that Uber on the one hand creates the supply and demand, and on the other exercises decisive influence over the conditions for the provision of such services, the other option is applicable, meaning that the services provided by Uber are to be considered as services in the field of transport, an integral part of which forms the intermediation service.

22 Judgement of the Court of 10 April 2018, C-320/16 Uber France. ECLI:EU:C:2018:221, p. 27 


\subsection{Airbnb}

Criteria established by the Court for the purpose of identifying the nature of services provided by Uber were later implemented by the Court in its recent judgement in the case C-390/18 Airbnb Ireland, in which the Court applied these criteria to Airbnb Ireland UC (hereinafter only as „Airbnb Ireland“) that operates the collaborative platform Airbnb.

Airbnb Ireland is a company established under Irish law with its seat in Dublin. The company's activities consist of the operation of an electronic platform that intermediates the conclusion of a contract for the provision of an accommodation service between hosts (professional or non-professional) and users looking for such accommodation on payment of a commission. Apart from the main service provided by Airbnb Ireland, the purpose of which is the centralization of the accommodation offers, the company also offers the hosts other ancillary services, such as:

a) a format for setting out the content of their offer,

b) optional photography services,

c) optional civil liability insurance,

d) optional guarantee against damages for up to EUR 800.000,

e) optional tool for estimating the rental price having regard to the market averages taken from that platform,

f) a ratings system, whereby the host and the guest can leave an evaluation on a scale of zero to five stars.

Moreover, Airbnb Ireland uses services provided by the company Airbnb Payments UK Ltd (hereinafter only as „Airbnb Payments") established under UK law with its seat in London. Airbnb Payments ensures the transfer of the rental price from the guest to the host, to which a commission is added in the amount of $6 \%$ to $12 \%$ for the provisions of Airbnb Ireland services.

As regards the relationships established between the individual users of the Airbnb platform and the platform itself, it may be stated (similarly as regards the platform Uber) that these are established on the basis of a contract conluded at the time of the registration of an individual (host or guest) on the platform. However, the situation is complicated by the fact that the users do not only conclude the contract for the use of platform with Airbnb Ireland, but also conclude a contract on the provision of a service consisting of the transfer of payments realised on this platform with Airbnb Payments. 
In addition, as regards the relationship established between the hosts and guests on the basis of commercial transactions concluded with the help of the platform, Article 1 (1.2) of the Airbnb's Terms of Services states that „As the provider of the Airbnb platform, Airbnb does not own, create, sell, resell, provide, control, manage, offer, deliver, or supply any Listings or Host Services, nor is Airbnb an organiser or retailer of travel packages under Directive (EU) 2015/2302. Hosts alone are responsible for their Listings and Host Services. When Members make or accept a booking, they are entering into a contract directly with each other. Airbnb is not and does not become a party to or other participant in any contractual relationship between Members, nor is Airbnb a real estate broker or insurer." 23

According to the Airbnb, it is necessary to strictly distinguish between, on the one hand, intermediation services provided by the platform to the individual hosts and guests (by Airbnb Ireland and Airbnb Payments), and on the other, accommodation services provided exclusively between the individual hosts and guests on the basis of a contractual relationship concluded between these parties without a participation of the platform.

The differentiation of the relationships established on the Airbnb platform was contested in the proceedings brought by the Association for Professional Tourism and Accommodation (hereinafter only as "AHTOP“), which lodged a complaint inter alia for the provision of services without the licence as required by French law. The AHTOP contested the argument that Airbnb Ireland merely connects its users through the platform, as it also provides other services that may amount to intermediation in property transactions. On the basis of this complaint, the Public Prosecutor attached to the Tribunal de grande instance de Paris brought charges against the Airbnb. The investigating judge later refered to the Court for a preliminary ruling the question of whether services provided by the Airbnb Ireland are to be interpreted as information society services as defined by the the relevant EU law, or not.

The Court firstly stated that the intermediation service in question (connecting professional or non-professional hosts with users seeking to rent their properties by means of an electronic platform) is a service within the meaning of Article 56 TFEU and the Directive 2006/123/EC. However, it is not clear whether this intermediation service is to be considered as an information society service within the meaning of Article 2 (a) of Directive 2000/31/EC on electronic commerce.

23 Article 1 (1.2) of the Airbnb Terms of Service. Available online: [https://sk.airbnb.com/ terms\#sec201910_1], accessed 20. June 2020 
To assess whether the service at issue in the main proceedings is an information society service the Court examined the fulfilment of the cumulative criteria that define the service as an information society service, specifically whether the service in question is normally provided for remuneration, at a distance, by electronic means and at the individual request of a recipient of services. As regards the first condition of the provision of a service for remuneration, it is clear that Airbnb Ireland provides its services for a commission (in the scope of 6 to $12 \%$ of the rental price) paid by the guest and not by the host. The second and third conditions consisting of the obligation to provide the service at a distance and by electronic means were also fulfilled due to the fact that the relationship between hosts and guests is established with the help of an electronic platform without the concurrent presence of the provider of the service on one hand and its users on the other (hosts and guests). Similarly, as regards the last condition of the service provision at the individual request of the services' recipient, the Court stated that this condition is met as hosts advertise their offers on the platform and users individually choose the offers best suited for them. Due to the fact that all of the above stated conditions were cumulatively satisfied, the Court held that the examined intermediation service can be considered as an information society service within the meaning of Article 2 (a) of Directive 2000/31/EC on electronic commerce.

In addition, the Court also analysed the argument, according to which the intermediation service in question is not subject to the specific liability regime established for the provision of information society services as it forms an integral part of the underlying accommodation service. In this regard the Court stated that such an intermediation service "cannot be separated from the property transaction itself, in that it is intended not only to provide an immediate accommodation service, but also on the basis of a structured list of the places of accommodation available on the electronic platform of the same name and corresponding to the criteria selected by the persons looking for short-term accommodation, to provide a tool to facilitate the conclusion of contracts concerning future interactions. It is the creation of such a list for the benefit of both of the hosts who have accommodation to rent and persons looking for that type of accommodation which constitutes the essential feature of the electronic platform managed by Airbnb Ireland." ${ }^{4}$ Due to this, because of its importance, "the compiling of offers using a harmonized format, coupled with tools for searching for, locating and comparing those offers, constitutes a service which cannot be regarded as merely ancillary to an overall service coming under a different legal classification, namely provision of an accommodation service." 25

\footnotetext{
24 Judgement of the Court of 19 December 2019, C-390/18 Airbnb Ireland. ECLI:EU:C:2019:1112, p. 53

25 Ibid., p. 54
} 
The first argument that led the Court to the above-stated conclusion is the fact that the intermediation service in question is not indispensable to the provision of accommodation service. Neither the hosts nor the guests are required to use the Airbnb platform to provide offers or search for the short-term rent of real estate. Even before the creation of the platform there were many ways in which hosts were able to offer their real estate for rent as well as ways in which guests looked for the available real estate (reality offices, advertisements in print/electronic form etc.). In this regard we may conclude that Airbnb Ireland does not create the supply and demand for accommodation services without which the provision of these services would not be possible.

The second argument in this regard concerns the fact that Airbnb Ireland does not in any way stipulate or limit the rent price (e. g. by establishing the minimum or maximum price) to be paid for the provision of an accommodation service. The fact that Airbnb Ireland provides hosts with an optional tool for estimating rental price having regard to the market averages taken from the platform does not challenge this conclusion, as the responsibility for setting the rent is left to the host alone.

Another argument in favour of the conclusion reached is the fact that none of the ancillary services provided by Airbnb Ireland, considered separately or together, "constitute an end in themselves, but rather a means of benefiting from the intermediation service provided by Airbnb Ireland or of offering accommodation services in the best conditions; (...) even taken together, the services, optional or otherwise, (...) do not call into question the separate nature of the intermediation service (...) and therefore its classification as an 'information society service', since they do not substantially modify the specific characteristics of that service." 26

The last argument formulated by the Court in this regard was the impossibility of comparing the services provided by Airbnb Ireland with services provided by Uber as examined by the Court in the case C-434/15 Uber Spain and in the case C-320/16 Uber France. The reason for this is, beside the fact that these judgements were adopted in the context of urban transport subject to Article 58 (1) TFEU, mainly the fact that it is not possible to establish that Airbnb Ireland exercises the same level of a decisive influence over the provision of the underlying accommodation service, as it does not determine the charged price and does not select service providers that may offer their services through its platform.

26 Judgement of the Court of 19 December 2019, C-390/18 Airbnb Ireland. ECLI:EU:C:2019:1112, p. 64 
On the basis of these arguments the Court stated that Airbnb Ireland provides an intermediation service that can be classified as in 'information society service' under the eCommerce Directive.

The main contribution of this decision is primarily the confirmation of the criteria established by the Court in its judgements in the case C-434/15 Uber Spain and in the case C-320/16 Uber France, as well as the further identification of the applicable legal regime as regards the services in question. Similarly as in the Uber decisions, the Court considered the criterion of the creation of supply and demand of services, whereby without the participation of a collaborative platform the functioning of the market in this area would not be possible, as well as the criterion of the existence of decisive influence of the collaborative platform over the conditions for the provision of such services.

In this regard we may consider the mutual relationship between the above stated criteria and their importance for the application in individual cases. It is, however, not clear from the analysis of the Court's decisions, whether these criteria stipulate cumulative conditions, the fulfilment of which signifies that the service in question cannot be separated from the underlying service, the result of which is the inapplicability of the liability regime established for the provision of information society services (despite of the fact that the service conforms to the definition of an information society service). Some guidance in this regard provides Advocate General Szpunar, according to whom: "The criterion relating to the creation of a supply of services constitutes only (...) an indication that a service provided by electronic means forms an inseparable whole with a service having material content. It is not sufficient that a service provider creates a new supply of services that are not provided by electronic means (...) [as] the creation of those services must be followed by the maintenance, under the control of that provider, of the conditions under which they are provided." 27 We support this conclusion, as the creation of a new form of the supply of services provided by electronic means may be replicated by other platforms or achieved through other means, but the way the platform operates and how it affects its users (whether service providers or those seeking such services) defines the nature of the different contractual relationships concluded with the help of the platform. Here the application of the contractual freedom - a principle generally recognized in continental law - may have to be limited for the purpose of providing protection to the concerned parties, especially as regards those platform users that fall into the category of consumers and therefore require a higher level of protection. Such an interference must be, however, based on specific objectives supported by the

27 Opinion of the Advocate General Szpunar delivered on 30 April 2019, C-390/18 Airbnb Ireland. ECLI:EU:C:2019:336, p. 65 
relevant legislation. The issue in the context of collaborative economy is, however, how to apply the existing legislation (consumer law, commercial law, etc.) on new transactions, the existence of which was not expected at the time of its adoption, specifically, how to adjust the existing legislation typically regulating bilateral relationships (e.g. between traders and consumers) to multilateral relationships concluded with the help of a platform. What must be noted in this regard is the fact that most types of services provided by collaborative platforms are not regulated on the European Union level (urban transport or accommodation), but are subject to the provisions of national law that may even differ in different regions or cities of the Member State. This, of course, may not only lead to legal uncertainty as to the applicability of the existing legislation but also to legal fragmentation hindering the cross-border provisions of services by collaborative platforms. In this case it will usually be national courts of individual Member States that will have to analyse the nature of services provided by collaborative platforms and the results (as is clear from the decisions already adopted) will probably differ due to the specificities of the analysed national law. It is questionable, whether national courts will be able to use the criteria established by the Court to differentiate between collaborative platforms acting as intermediaries or as providers of the underlying services. The following section of this paper outlines the second step needed for the consideration of the position held by collaborative platforms.

\section{DISCUSSION}

The above stated analysis presents only the first step in understanding the services provided by collaborative platforms within the collaborative economy. The next step would be the analysis of the contractual relationships that are established between the individual subjects participating in the collaborative economy, namely collaborative platforms and its users, who include service providers on the one hand and users of these services on the other. It is also necessary to distinguish different categories of service providers, as these can be professionals acting within their trade, business, craft or profession, or non-professionals that act outside their trade, business, craft or profession and that may even be classified as consumers under the provisions of consumer law. This categorization of subjects will determine the applicability of legislation (commercial law as regards relationships established between collaborative platforms and professional service providers or consumer law as regards relationships established between collaborative platforms and non-professional service providers), the establishment of liability (of the collaborative platform or of the service provider), as well as the possibility to establish an employment relationship between collaborative platforms and service provid- 
ers, if certain criteria are met (criterion of remuneration, criterion of the nature of work and subordination criterion).

The important factor to be considered in this regard is the fact that the relationships established within the collaborative economy are contractually based. In practice this is accomplished by concluding contracts between collaborative platforms on the one hand and its users on the other at the time of the user's registration on the platform, whereby users must agree with the terms of conditions as stipulated by the platform. Due to the applicability of the contractual freedom principle, we may argue that the way in which the nature of the relationship between the collaborative platform and its users is defined, must be acknowledged. However, such classification will not always correspond to the reality (as was clear from the analysis provided in the previous text e. g. as regards Uber and its relationship to its drivers). Due to this it will be necessary, e. g. when determining the party liable for the non-performance of the underlying service, to examine the true nature of the individual contractual relationships that resulted from the cooperation of the collaborative platform and its users, and whether this corresponds to what the platform claims.

Another factor to be considered is the absence of legislation applicable in the case when the Directive 2000/31/ES on electronic commerce is deemed inapplicable due to the fact that the collaborative platforms in question provides underlying services, the integral part of which form information society services. In such a case it is difficult to determine the applicable European Union legislation, as services in question (e. g transport services, accommodation services) will usually be regulated on the national level by the legislation of individual Member States. The need to apply national legislation that differs from one Member State to another results in the legal fragmentation and legal uncertainty hindering possible cross-border expansion of the collaborative platforms' services due to high costs of adapting to different legal regimes in individual Member States. This undesirable outcome will undoubtedly limit the expansion of the digital single market as imagined by the Commission in its Digital Single Market Strategy for Europe. ${ }^{28}$ Moreover, even in the case when the Directive 2000/31/ES on electronic commerce is applicable,

28 See: Communication from the Commission to the European Parliament, the Council, the European Economic and Social Committee and the Committee of the Regions. A Digital Single Market Strategy for Europe. COM/2015/0192 final 
this Directive excludes from its scope such legal areas as tax law ${ }^{29}$, consumer law ${ }^{30}$, personal data protection law $^{31}$ or competition law ${ }^{32}$, within which liability of collaborative platforms may arise if the relevant obligations stemming from these legal areas are infringed.

\section{CONCLUSION}

The objective of this paper was the analysis of the nature of services provided by collaborative platforms. As the Commission stated, collaborative platforms can be the providers of information society services, underlying services or ancillary services. In this regard it is, therefore, necessary to examine the nature of services provided by a collaborative platform individually, taking into account all of the relevant aspects. The question of whether collaborative platforms act as providers of the underlying service is key in order to determine the applicability of the liability exemptions as stipulated by the Directive 2000/31/EC.

The Commission considers as the determining factor in this regard the level of influence or control exerted by the collaborative platform over the service provider. In order to determine the level of influence or control exerted by a platform, the Commission stated as the relevant criteria to be examined the criterion of price,

29 In the context of the collaborative economy see: Pantazatou, K., Taxation of the Sharing Economy in the European Union, in: Davidson, N. M. et al. (eds.), The Cambridge Handbook of The Law of the Sharing Economy, Cambridge: Cambridge University Press, 2018, pp. 368-380; Viswanathan, M., Tax Compliance and the Sharing Economy, in: Davidson, N. M. et al. (eds.), The Cambridge Handbook of The Law of the Sharing Economy, Cambridge: Cambridge University Press, 2018, pp. 357-367; Barry, J. M., Taxation and Innovation - The Sharing Economy as a Case Study, in: Davidson, N. M. et al. (eds.), The Cambridge Handbook of The Law of the Sharing Economy, Cambridge: Cambridge University Press, 2018, pp. 381-393

30 In the context of the collaborative economy see: Devolder, B., Contractual Liability of the Platform, in: The Platform Economy. Unravelling the Legal Status of Online Intermediaries, Cambridge: Intersentia Ltd, 2019, pp. 31-87; Domurath, I., Platforms as Contract Partners: Uber and beyond, in: Maastricht Journal of European Comparative Law, vol. 25, no.5, 2018, pp. 565-581

31 In the context of the collaborative economy see: Lloyd, I. J. Information Technology Law, 8th edition, Oxford: Oxford University Press, 2017, pp. 1-201; Riordan, J., The Liability of Internet Intermediaries, Oxford: Oxford University Press, 2016, pp. 290-352; Polčák, R., Právo informačních technologií, Praha: Wolters Kluwer ČR, 2018, pp. 391-485

32 In the context of the collaborative economy see: Bostoen, F., Competition Law in the Peer-to-Peer Economy, in: Devolder, B. (ed.), The Platform Economy. Unravelling the Legal Status of Online Intermediaries, Cambridge: Intersentia Ltd, 2019, pp. 143-171; King, S. P., Sharing Economy: What Challenges for Competition Law?, Journal of European Competition Law \& Practice, vol. 6, no. 10, 2015, pp. 729734.; Capobianco, A.; Nyeso, A. Challenges for Competition Law Enforcement and Policy in the Digital Economy, Journal of European Competition Law \& Practice, vol. 9, no. 1, 2017, pp. 19-27; Lougher, G.; Kalmanowicz, S., EU Competition Law in the Sharing Economy, Journal of European Competition Law \& Practice, vol. 7, no. 2, 2015, pp. 87-101 
the criterion of stipulating other key contractual terms and the criterion of the ownership of key assets. In addition, other factors may also be considered, such as the fact that the platform incurs the costs and assumes all the risks related to the provision of the underlying service or if an employment relationship exists between the platform and the provider of the underlying service. The criteria stated, especially the criterion of the ownership of key assets, were later criticized, due to their conflict with the way in which the collaborative economy operates.

Due to the non-binding nature of the Commission's guidelines, the author closely examined the individual judgements adopted by the Court of Justice that approached the issue of determining the nature of services provided by collaborative platforms in a less restrictive manner. The Court firstly analysed whether the services provided by collaborative platforms Uber and Airbnb fulfil the definition criteria of the 'information society service'. The Court later examined the relationship between the information society services provided by platforms and the underlying services that form the substance of commercial transactions concluded on platforms. Specifically, the Court considered whether the information society services form an integral part of the underlying service (transport or accommodation service) or not. In this regard the Court identified as the relevant criteria the criterion of the creation of the supply and demand and the criterion of the decisive influence exercised over the provision of the underlying service. The decisive influence criterion can be determined e. g. by defining the subject stipulating the final price for the underlying service provided, collecting the final price from the user, exercising the control over the shared assets' quality or over the persons providing the underlying services, as well as by examining the nature of ancillary services provided by the platform. The application of these criteria enabled the Court to determine, whether information society services provided by collaborative platforms can (Airbnb) or cannot (Uber) be separated from the underlying service.

The application of these criteria on other collaborative platforms not yet examined by the Court will demonstrate their functionality and can help the individual Member States in the process of adopting appropriate regulation on the functioning of collaborative platforms in their territory. Moreover, these criteria should be complemented by the examination of the individual multilateral contractual relationships concluded between the subjects participating in the collaborative economy, which will predominantly be based on the provisions of national law of the Member States. 


\section{REFERENCES}

\section{BOOKS AND ARTICLES}

1. Barry, J. M., Taxation and Innovation - The Sharing Economy as a Case Study, in: Davidson, N. M. et al. (eds.), The Cambridge Handbook of The Law of the Sharing Economy, Cambridge: Cambridge University Press, 2018, pp. 381-393

2. Bostoen, F., Competition Law in the Peer-to-Peer Economy, in: Devolder, B., The Platform Economy. Unravelling the Legal Status of Online Intermediaries, Cambridge: Intersentia Ltd, 2019, pp. 143-171

3. Capobianco, A.; Nyeso, A., Challenges for Competition Law Enforcement and Policy in the Digital Economy, Journal of European Competition Law \& Practice, vol. 9, no. 1, 2017, pp. 19-27

4. Devolder, B., Contractual Liability of the Platform, in: The Platform Economy. Unravelling the Legal Status of Online Intermediaries, Cambridge: Intersentia Ltd, 2019

5. Domurath, I., Platforms as Contract Partners: Uber and beyond, Maastricht Journal of European Comparative Law, vol. 25, no. 5, 2018, pp.565-581

6. Hučková, R.; Červená, K., Commerce and Technological Development, in: DAYS OF LAW 2014, part 4: Technological Development and Law. Brno: Masaryk University, 2015, pp. 99-107

7. Hučková, R., New Mechanisms for the Protection of Consumer Rights. in: Studia Iuridica Cassoviensia, 2016, pp. 46-55

8. King, S. P., Sharing Economy: What Challenges for Competition Law?, Journal of European Competition Law \& Practice, vol. 6, no. 10, 2015, pp. 729-734

9. Lloyd, I. J. Information Technology Law, 8th edition, Oxford: Oxford University Press, 2017, pp. 1-201

10. Lougher, G.; Kalmanowicz, S., EU Competition Law in the Sharing Economy, Journal of European Competition Law \& Practice, vol. 7, no. 2, 2015, pp. 87-101

11. Pantazatou, K., Taxation of the Sharing Economy in the European Union, in: Davidson, N. M. et al. (eds.), The Cambridge Handbook of The Law of the Sharing Economy, Cambridge: Cambridge University Press, 2018, pp. 368-380

12. Polčák, R., Právo informačnich technologii. Praha: Wolters Kluwer ČR, 2018, pp. 391-485

13. Riordan, J. The Liability of Internet Intermediaries, Oxford: Oxford University Press, 2016, pp. 290-352

14. Treščáková, D., The Impact of Digitalization and Innovation in International Trade, in: Cifrovoje parvo, Moscow: Prospekt, 2020

15. Treščáková, D.; Hučková, R., Specific Aspects of Personal Data Protection in Electronic Commerce, in: Days of Law 2015: System Questions of Private Law. Brno: Masaryk University, 2016, pp. 105-119

16. Viswanathan, M., Tax Compliance and the Sharing Economy, in: Davidson, N. M. et al. (eds.), The Cambridge Handbook of The Law of the Sharing Economy, Cambridge: Cambridge University Press, 2018, pp. 357-367 


\section{EU LAW}

1. Directive 2006/123/EC of the European Parliament and of the Council of 12 December 2006 on services in the internal market, OJ L 376, 27.12.2006

2. Communication from the Commission to the European parliament, the Council, the European Economic and Social Committee and the Committee of Regions. A European Agenda for the Collaborative Economy. (SWD (2016) 184 final)

3. Communication from the Commission to the European Parliament, the Council, the European Economic and Social Committee and the Committee of the Regions. A Digital Single Market Strategy for Europe. COM/2015/0192 final

4. Treaty on the Functioning of the European Union, OJ C 326, 26.10.2012

\section{CJEU CASE LAW}

1. Judgement of the Court of 15 October 2015, C-168/14, Grupo Itevelesa and others

2. Opinion of the Advocate General delivered on 11. May 2017, C-434/15 Asociación Profesional Elite Taxi

3. Opinion of the Advocate General delivered on 4 July 2017, C-360/12 Uber France

4. Judgement of the Court of 20 December 2017, C-454/15 Asociación Profesional Elite Taxi

5. Judgement of the Court of 10 April 2018, C-320/16 Uber France

6. Opinion of the Advocate General delivered on 30 April 2019, C-390/18 Airbnb Ireland

7. Judgement of the Court of 19 December 2019, C-390/18 Airbnb Ireland

\section{OTHER}

1. Airbnb Terms of Service, Available online: [https://sk.airbnb.com/terms\#sec201910_1], accessed 20. June 2020

2. Uber's Terms of Service, Available online: [https://www.uber.com/legal/en/document/?name=general-terms-of-use\&country=united-states\&lang=en], accessed 20 . June 2020 